\title{
BIMBINGAN TEKNIK PENGOLAHAN PAKAN AYAM KAMPUNG FASE PETELUR BAGI KELOMPOK WANITA TANI REZEKI KARTINI KELURAHAN GUNTUNG PAYUNG KECAMATAN LANDASAN ULIN KOTA BANJARBARU
}

\author{
Siti Dharmawati dan Nordiansyah Firahmi \\ Jurusan Peternakan, Fakultas Pertanian, Universitas Islam Kalimantan \\ Email : $\underline{\text { dharmauniska@gmail.com }}$
}

\begin{abstract}
ABSTRAK
Mitra yang dilibatkan pada kegiatan Kemitraan Bagi Masyarakat (PKM) adalah Kelompok Wanita Tani Rezeki Kartini Kelurahan Guntung Payung Kecamatan Landasan Ulin Kota Banjarbaru Kalimantan Selatan.Spesialisasi usahanya adalah budidaya tanaman pangan, sayur-sayuran dan beternak ayam buras. Kendala yang dihadapi KWT Rezeki Kartini (1) Harga pakan yang tidak stabil dan mengalami kenaikanan sampai 4 kali dalam setahun (2) Tidak memiliki keahlian dalam membuat formulasi pakan sendiri (3) Ketersediaan bibit unggul yang tidak kontinyu (4) Kurangnya pemahamanan terhadap penanganan dan pencegahan penyakit. Permasalahan-permasalahan tersebut terjadi disebabkan : (1) Kurangnya informasi tentang hasil-hasil penelitian yang langsung menyentuh ke peternak terutama dalam hal pengolahan pakan dan teknologinya. (2) Rendahnya kemampuan dan keterampilan anggota dalam mengolah bahan-bahan pakan lokal (3) Kurangnya kesempatan bagi peternak untuk ikut pelatihan dan magang di perusahaan-perusahaan besar dan komersil di luar daerah. Luaran kegiatan ini adalah : (1) Luaran Solusi 1 sampai dengan solusi 3 : Mitra dapat menguasai teknik pemeliharaan ayam buras dengan baik dan mampu membuat formulasi ransum yang tepat, murah dan efisien. Selain itu peserta mampu mengadaptasi ilmu teknologi pengolahan pakan khususnya teknologi pengolahan silase keong rawa dan kepala udang. (2) Luaran solusi 4 : Mitra mampu melakukan perhitungan biaya produksi berdasarkan analisia usaha atau manajemen agribisnis yang tepat (3) Produk yaitu formulasi ransum untuk ayam buras. Metode kegiatan yang dilaksanakan adalah (1) Wawancara langsung (2) Pelatihan teoritis (metode kelas) (3) Praktek langsung yang dilaksakanakan oleh mitra dengan bimbingan tim pelaksana. Khalayak sasaran adalah anggota kelompok wanita tani Rezeki Kartini. Hasil kegiatan pengabdian ini anggota kelompok sudah memahami cara pembuatan pakan fermentasi dengan berbagai bahan pakan lokal, dan sebagian sudah menerapkannya sebagai bahan campuran ransum ayam kampong fase petelur yang dipelihara secara intensif. Hasil pengamatan dan observasi menunjukkan bahwa ternak ayam kampung yang diberi ransum fermentasi ransum menunjukkan performans yang baik. Ayam kampung yang dipelihara di Kelompok KWT Rezeki Kartini mulai bertelur rata-rata umur $6-7$ bulan, puncak produksi pada umur antara $12-18$ bulan. Berat telur yang dihasilkan berkisar $35-47 \mathrm{~g} / \mathrm{butir}$.
\end{abstract}

\section{PENDAHULUAN}

Ayam buras merupakan salah satu jenis ternak yang sangat potensial untuk dikembangkan karena dapat dipelihara pada skala rumah tangga sehingga dapat meningkatkan perekonomian keluarga. 
Selain itu harga ayam buras relatif lebih stabil dibandingkan ayam broiler dengan harga jual yang lebih tinggi. Selain itu salah satu keistemewaan dari ayam buras adalah mampu dipelihara di pekarangan. Pekarangan merupakan agroekosistem yang baik dan sangat berpeotensi dalam memenuhi kebutuhan hidup masyarakat atau pemiliknya bahkan jika dikembangkan secara baik akan bermanfaat untuk mempertahankan ketahanan pangan keluarga, masyarakat sekitar guna pemenuhan kebutuhan pasar. Salah satu yang dikembangkan dikembangkan adalah ayam buras

Mitra yang dilibatkan pada kegiatan Kemitraan Bagi Masyarakat (PKM) adalah Kelompok Wanita Tani Rezeki Kartini yang berkedudukan di Jalan Sidomulyo I RT 02 Kelurahan Guntung Payung Kecamatan Landasan Ulin Kota Banjarbaru Kalimantan Selatan.KWT Rezeki Kartini berdiri pada tahun 2016 dengan anggota 18 orang Basis usaha KWT ini adalah mengelola pekarangan dengan didominasi usaha pertanian, tanaman apotik hidup/toga (tanaman obat keluarga) dan memanfaatkan pekarangannya untuk budidaya peternakan unggas dengan rata-rata kepemilikan ternak 100-300 ekor . Selain itu KWT Rezeki Kartini sudah mendapat CSR dari Pertamina sejak tahun 2017 dengan bidang usaha tanaman hidroponik, tanaman obat. Salah satu keistemewaan dari kelompok wanita tani ini adalah sebagian besar anggota memiliki pekarangan yang cukup luas rata-rata $15 \mathrm{~m} \mathrm{x} 20 \mathrm{~m}$ sampai dengan $30 \mathrm{~m}$ x $50 \mathrm{~m}$. Sehingga dengan kondisi tersebut pemanfaatan pekarangan lebih dapat dioptimalkan.

Kelompok Wanita Tani Rezeki Kartini spesialisasi usahanya adalah budidaya tanaman pangan, sayursayuran dan beternak ayam buras. Dipilihnya kelompok Rezeki Tani karena (1) anggota kelompok mitra ini mempunyai komitmen yang kuat untuk mengembangkan usahanya (wirausaha) dan mempunyai visi dan misi yang jelas serta bersedia menerima inovasi dan ipteks (2) memiliki komitmen yang kuat untuk maju, meningkatkan pendapatan keluarga (3) Luas areal pekarangan rumah yang dimiliki anggota kelompok berkisar $500 \mathrm{~m}^{2}$ $1500 \mathrm{~m}^{2} \quad$ (3) Ternak yang yang dipelihara sebagian besar adalah ayam buras yang dipelihara secara semi intensif dan intensif dengan menggunakan kandang panggung 
sistem koloni. (4) Walaupun peternakan berada di lingkungan pemukiman ternyata mitra mampu mengatasi bau kandang sehingga tidak menyebabkan polusi udara bagi lingkungan sekitarnya sesuai arahan pelaksana IbM pada tahun 2013.

Khusus untuk peternakan ayam buras KWT Rezeki Kartini mengalami berbagai kendala dalam pengembangannya antara lain :(1) Harga pakan yang tidak stabil dan mengalami kenaikanan sampai 4 kali dalam setahun (2) Tidak memiliki keahlian dalam membuat formulasi pakan sendiri (3) Ketersediaan bibit unggul yang tidak kontinyu Kurangnya pemahamanan terhadap penanganan dan pencegahan penyakit. Permasalahan-permasalahan tersebut terjadi disebabkan : (1) Kurangnya informasi tentang hasil-hasil penelitian yang langsung menyentuh ke peternak terutama dalam hal pengolahan pakan dan teknologinya. (2) Rendahnya kemampuan dan keterampilan anggota dalam mengolah bahan-bahan pakan lokal (3) Kurangnya kesempatan bagi peternak untuk ikut pelatihan dan magang di perusahaan-perusahaan besar dan komersil di luar daerah. Secara umum ayam buras mempunyai sifat yang mudah stres, peka lingkungan dan sangat pemilih dalam hal pakan dalam hal Mitra sangat tergantung dengan pakan pabrik dan belum menguasai pengolahan pakan lokal

Keterbatasan peralatan pengolahan pakan khususnya perlatan untuk pengering pakan (oven) (4) Mitra kurang memahami cara penanganan penyakit ayam buras, mengenali gejala penyakit dan biosekuriti masih lemah sehingga jika terjadi wabah penyakit akan merugikan mitra. Berdasarkan kesepakatan dengan Kelompok Wanita Tani REZEKI KARTINI sebagai mitra dari kegiatan ini maka metode yang ditawarkan untuk mendukung realisasi program pengabdian kepada masyarakat bagi peternak ayam buras adalah sebagai berikut :

1. Solusi yang diperlukan oleh mitra pada saat ini adalah pengetahuan dan keterampilan serta penguasaan metode/teknik pengolahan bahan pakan lokal bagi ternak ayam buras yaitu berupa bahan -bahan pakan lokal

2. Pengenalan penyakit dan biosekuriti kandang

3. Manajemen teknis pemeliharaan ayam buras meliputi pemlihan 
bibit, model perkandangan, $\underline{\text { manajemen pakan, penyakit dan }}$ manajemen pembibitan.

\section{METODE KEGIATAN}

Metode pendekatan untuk mendukung realisasi program pengabdian kepada masyarakat bagi peternak mitra adalah sebagai berikut :

a. Wawancara langsung kepada para peternak mitra kemudian diidentifikasi permasalahan mitra yang sangat mendesak dan dirasakan penting bagi kelangsungan usaha peternakan ayam buras mitra.

b. Pelatihan teoritis (metode kelas) teknik pemeliharaan ayam buras secara umum (pengenalan bibit, sistem perkandangan, metode pemberian ransum dan penanganan penyakit), teknik pengolahan dan pengawetan pakan khususnya pengolahan dan pengawetan pakan.

c. Pelatihan dalam hal manajemen usaha peternakan ayam secara profesional

d. Praktek langsung yang dilaksakanakan oleh mitra dengan bimbingan tim pengusul meliputi kegiatan penyiapan bibit ayam buras (DOC), cara memilih dan mengenali bahan-bahan pakan yang berkualitas, perhitungan nilai gizi ransum, menyusun dan membuat formulasi ransum, pencampuran ransum, pembibitan itik, penangananm penyakit dan biosekuriti, pemilihan telur tetas dan cara penetasan agar berhasil.

Khalayak sasaran kegiatan pengabdian kepada masyarakat ini adalah anggota kelompok wanita tani Rezeki Kartini.

\section{PEMBAHASAN}

\section{Kondisi Umum Kelompok Wanita}

Tani Rezeki Kartini

KWT Rezeki Kartini berdiri pada tahun 2016 dengan anggota 18 orang yang beranggotakan ibu-ibu rumah tangga dikukuhkan oleh Lurah Guntung Payung Fajar Asrori dengan nomor Pengesahan 420/001/ekobang tanggal 08 April 2016. Basis usaha KWT ini adalah mengelola pekarangan dengan didominasi usaha pertanian, tanaman apotik hidup/toga (tanaman obat keluarga) dan memanfaatkan pekarangannya untuk budidaya peternakan unggas dengan rata-rata kepemilikan ternak 100-300 ekor. Selain itu KWT Rezeki Kartini sudah mendapat CSR dari Pertamina sejak 
tahun 2017 dengan bidang usaha tanaman hidroponik, tanaman obat. Salah satu keistemewaan dari kelompok wanita tani ini adalah sebagian besar anggota memiliki pekarangan yang cukup luas rata-rata $15 \mathrm{~m}$ x $20 \mathrm{~m}$ sampai dengan $30 \mathrm{~m}$ x $50 \mathrm{~m}$. Sehingga dengan kondisi tersebut pemanfaatan pekarangan lebih dapat dioptimalkan.

\section{Ketua}

\section{Sekretaris}

\section{Seksi Produksi}

\section{Bendahara}

Gambar 1.Struktur Organisasi KWT Rezeki Kartini

\section{Gambaran Umum Kegiatan}

Pengabdian

Pendampingan kegiatan yang dilaksanakan dari bulan Nopember 2018 sampai dengan bulan Januari 2019. Kegiatan yang dilakukan untuk mengatasi persoalan mitra adalah :

1. Pelatihan teoritis (metode kelas) teknik pemeliharaan ayam secara umum (pengenalan bibit, sistem perkandangan, metode pemberian ransum dan penanganan penyakit), teknik pengolahan dan pengawetan pakan dengan menggunakan metode silase, cara pencampuran bahan, pemilihan bahan, cara penyimpanan bahan sampai terbentuknya bahan pakan. Selain itu diajarkan juga pada para anggota mitra beberapa metode pencampuran ransum yang tepat dengan memanfaatkan bahan-bahan pakan lokal yang murah, mudah diperoleh, tidak mengandung anti nutrisi, bernilai gizi tinggi sehingga dihasilkan ransum itik yang berkualitas dan mampu meningkatkan produksi ternak itik. 
2. Pengolahan pakan dengan metode fermentasi dedak dan empulur sagu dengan menggunakan metode yang mudah diserap dan diadaptasi oleh para anggota mitra

3. Praktek langsung yang dilaksakanakan oleh mitra dengan bimbingan tim pengusul IbM meliputi kegiatan penyiapan bibit , cara memilih dan mengenali bahanbahan pakan yang berkualitas, perhitungan nilai gizi ransum, menyusun dan membuat formulasi ransum, pencampuran ransum, Bimbingan ini dilakukan sampai mitra dianggap cukup terampil dan menguasai materi.

4. Pelatihan yang diberikan adalah membuat pakan fermentasi. Bahan fermentasi adalah dedak padi atau ampas sagu sebanyak $50 \quad \mathrm{~kg}$ dicampur dengan ragi tape sebanyak $2 \%$ dari berat bahan yang digunakan, mineral B12 sebanyak 15 gram. Bahan-bahan tersebut diaduk sampai homogeny mulai dari bahan yang jumlahnya paling sedikit ke jumlah bahan yang paling banyak. Kemudian campuran yang sudah homogeny dimasukkan ke dalam drum plastic atau bak plastic dengan cara dipadatkan dan pada permukaannya ditutup dengan daun pisang. Selanjutnya baha-bahan pakan lokal yang sudah difermentasi tadi disimpan selama 3-5 hari secara an aerob. Setelah bahan pakan dapat digunakan dengan cara dicampur dengan bahan bahan pakan lain. Biasanya bahan pakan hasil fermentasi dapat digunakan antara 30-40\% dalam ransum.
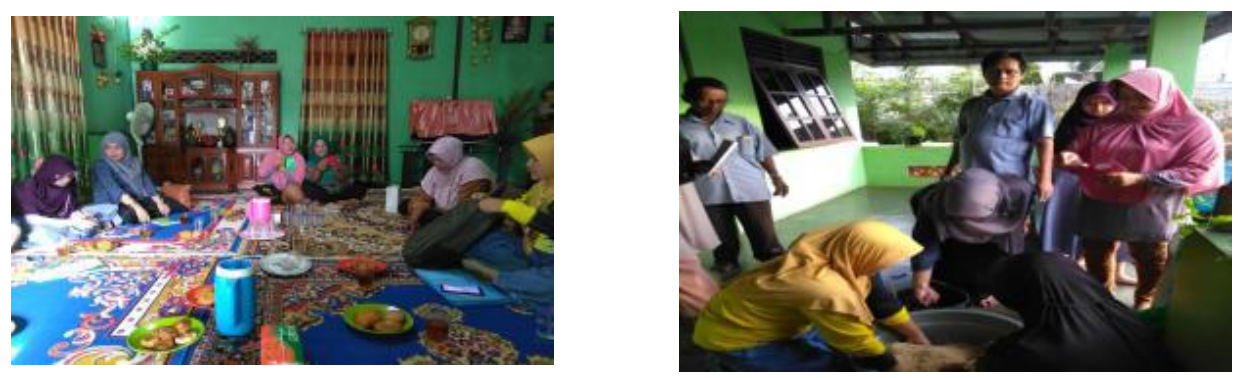

Gambar 1 dan 2. Penyuluhan di KWT Rezeki Kartini

Adapun Contoh Komposisi Ransum yang dibuat peternak disajikan pada Tabel 1 dan Tabel 2. 
Tabel 1.Contoh Formulasi Ransum ayam petelur dengan konsentrat

\begin{tabular}{llc}
\hline No. & NamaBahan & Jumlahdigunakan \\
\hline 1. & DedakPadi & $25,5 \mathrm{~kg}$ \\
2. & Konsentrat & $3,0 \mathrm{~kg}$ \\
3. & TepungIkan & $12 \mathrm{~kg}$ \\
4. & Ampas Tempe & $58 \mathrm{~kg}$ \\
5. & Premix & $0,5 \mathrm{~kg}$ \\
6. & TepungKapur & $1,0 \mathrm{~kg}$ \\
\hline & Jumlah & $100 \mathrm{~kg}$ \\
\hline
\end{tabular}

Kadar Protein : $\pm 17,75 \%$, Energi Metabolis $\pm 2712 \mathrm{Kkal} / \mathrm{kg}$, Perkiraan harga per Desember 2018Rp. 4.205

Tabel 2. Contoh Formulasi Ransum Ayam Petelur dengan konsentrat

\begin{tabular}{llc}
\hline No. & NamaBahan & Jumlahdigunakan \\
\hline 1. & DedakPadi & $23 \mathrm{~kg}$ \\
2. & Cangkangudang & $12 \mathrm{~kg}$ \\
3. & Sagu/paya & $5 \mathrm{~kg}$ \\
4. & Minyakkelapa & $3 \mathrm{~kg}$ \\
5. & Mineral & $1 \mathrm{~kg}$ \\
7. & Top mix & $1 \mathrm{~kg}$ \\
8. & TepungLimbah Roti & $40 \mathrm{~kg}$ \\
9 & Konsentrat & $15 \mathrm{~kg}$ \\
\hline & & $100 \mathrm{~kg}$ \\
\hline
\end{tabular}

Kadar Protein : $\pm 21 \%$, Energi Metabolis $\pm 2793 \mathrm{Kkal} / \mathrm{kg}$, Perkiraan harga per Desember 2018 Rp. 3.655

Dari hasil kegiatan pengabdian ini secara umum anggota kelompok sudah memahami cara pembuatan pakan fermentasi dengan berbagai bahan pakan lokal, dan sebagaian sudah menerapkannya sebagai bahan campuran ransum ayam kampong fase petelur yang dipelihara secara intensif. Penggunaan pakan fermentasi dalam ransum ini merupakan salah satu alternatif yang dapat digunakan untuk mengurangi biaya ransum yang cukup tinggi dengan harga pakan komersial yang terus meningkat. Hasil pengamatan dan observasi menunjukkan bahwa ternak ayam kampung yang diberi ransum fermentasi ransum menunjukkan performans yang baik. Selain itu lingkungan kandang tidak berbau, konsumsi ransum ayam kampong meningkat dan daya tahan tubuh ternak baik. 
Tabel 3.Jumlah Pakan yang Diberikan Mitra

\begin{tabular}{cccc}
\hline No. & $\begin{array}{c}\text { Jumlah Pakan yang } \\
\text { Diberikan (g/ekor) }\end{array}$ & Jumlah peternak & $\begin{array}{c}\text { Persentase } \\
(\%)\end{array}$ \\
\hline 1. & 80 & 5 & 27,78 \\
2. & 100 & 3 & 16,67 \\
3. & 150 & 10 & 55,55 \\
\hline
\end{tabular}

Jumlah pakan yang diberikan adalah 80 g/ekor - 150 g/ekor. Bahanbahan pakan diperoleh dari pembelian dan sisa sisa rumah tangga. Pemberian pakan 2 kali sehari dilaksanakan pada pagi pukul 07.00 wita dan sore hari pukul 16.00 wita. Sedangkan air minum diberikan 2 kali sehari yang berasal dari air sumur secara ad libitum. Penempatan air diletakkan dalam baskom plastik.

\section{Indikator keberhasilan}

Dilakukan evaluasi kegiatan keberhasilan program P2M dengan indikator sebagai berikut :

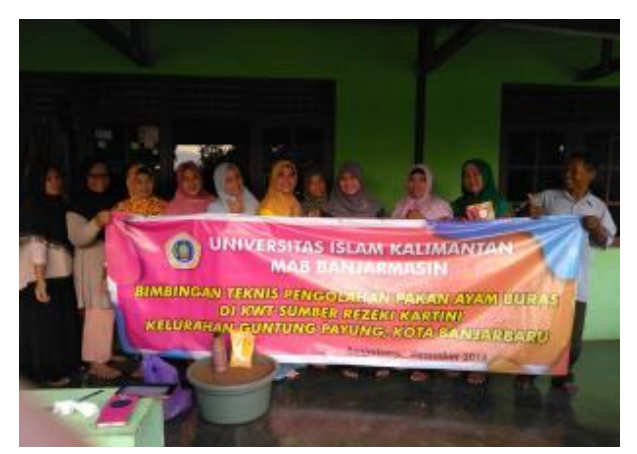

Gambar 3. Anggota KWT Sumber Rezeki Kartini
- Mitra memahami bibit ayam kampung yang baik, sehat dan produktif

- Memilih bahan-bahan pakan yang berkualitas

- Mampu menyusun formulasi ransum dengan metode sederhana yang telah diajarkan.

- Mampu membuata pakan fermentasi sehingga dihasilkan produk yang berkualitas, bernutrien tinggi dan bebas toksik.

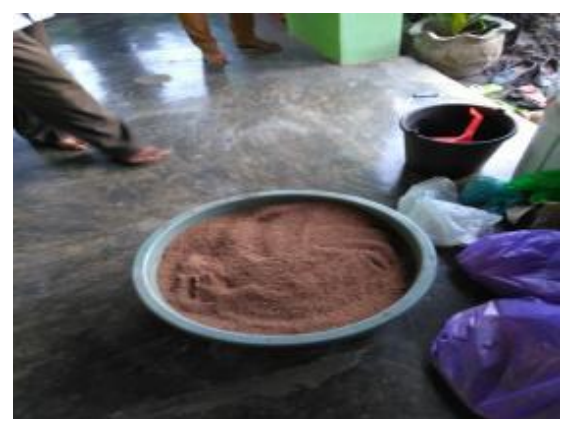

Gambar 4. Produk Pakan yang dihasilkan 


\section{Kapasitas Produksi dan Omzet}

Ayam kampung yang dipelihara di Kelompok KWT Rezeki Kartini mulai bertelur rata-rata umur $6-7$ bulan, puncak produksi pada umur antara 12 - 18 bulan. Berat telur yang dihasilkan berkisar 35 - 47 g/butir.

Tabel 4 .Produksi Telur Itik Mitra

\begin{tabular}{rrcc}
\hline No & Produksi Telur $(\%)$ & JumlahPeternak (jiwa) & Persentase $(\%)$ \\
\hline 1. & 38 & 11 & 61,11 \\
2. & 44 & 4 & 22,22 \\
3 & 53 & 3 & 16,67 \\
\hline
\end{tabular}

Tabel 4 menunjukkan rata-rata responden mempunyai ayamkampung dengan produksi $38 \%$ per tahun. Produksi ini relative rendah.

Pengambilan telur ayam kampong dilakukan setelah diperkirakan semua ayam sudah selesai bertelur, yaitu setiap pukul 08.00 wita. Hal ini dilakukan rutin agar tidak mengganggu ayam yang sedang mengalami proses bertelur sehingga tidak mengalami stress.

Harga telur berkisar antara $\mathrm{Rp}$. 2000,- $\quad$ sampai $\quad$ Rp2500,-/butir, sedangkan ayam kampong afkir dengan harga antara Rp. 70.000,- sampai Rp. 125.000,-/ekor.

\section{Kontribusi Mitra}

Peran serta anggota kelompok tani dalam kegiatan sangat aktif. Hal ini terlihat dari respon dalam menerima inovasi teknologi yang ditawarkan, ratarata kehadiran $100 \%$ dalam setiap kali pertemuan dan sebagian besar peserta aktif bertanya yang berhubungan dengan manajemen dan teknologi pemeliharaan dan pengolahan pakan.

\section{Keberlanjutan}

Sebagian besar anggota kelompok tani yang mengikuti kegiatan $\mathrm{P} 2 \mathrm{M}$ ini mempunyai harapan keberlanjutan dari program ini yaitu dalam bentuk pembinaan usaha kelompok, dimana usaha tersebut bukan saja dalam hal pembesaran ayam kampung, tetapi juga meliputi penganeka ragaman daging yang dihasilkan berupa produk yang mudah dipasarkan. Keputusan yang diambil atas musyawarah dari para anggota kelompok ternak. Hingga saat ini para anggota kelompok menggulirkan dana hasil penjualan itik di dalam anggota kelompoknya sendiri, yaitu dengan memelihara ayam kampung petelur dan pedaging. 


\section{Produk Kegiatan yang Dinilai Bermanfaat}

Produk kegiatan yang dianggap bermanfaat bagi masyarakat adalah pengetahuan tentang teknologi pengolahan pakan dan penyusunan ransum ayam fase starter dan fase finisher. Selain itu adanya pengetahuan dan praktek pengolahan pakan lokal yang difermentasi. Selain itu dalam kegiatan ini disumbangkan juga alat pencampur bahan pakan (mixer) yang berfungsi untuk mencampur bahan pakan itik yang sudah disusun agar homogen.

\section{Beberapa Permasalahan lain yang terekam}

Beberapa permasalahan yang terekam setelah kegiatan P2M ini adalah keterbatasan modal bagi peternak, kurangnya pelatihan dari instansi terkait dan beberapa anggota kelompok peternak (tidak mandiri) dalam hal pengambilan keputusan untuk maju. Walaupun demikian masih khusus pada kelompok cukup menonjol dan mempunyai kemauan untuk maju.

\section{KESIMPULAN}

Dari hasil kegiatan pengabdian kepada masyarakat diketahui bahwa respon peternak sangat baik dan sangat mendukung terhadap program yang dilaksanakan.

\section{DAFTAR PUSTAKA}

Anonim, 2009. Kecamatan Banjarbaru dalam Angka. Badan Pusat Statistik Pemerintah Kota Banjarbaru, hal : 36

Anonim, 2016. Profil Kelompok Wanita Tani Rezeki Kartini. Kelurahan Guntung Payung, Kecamatan Landasan Ulin. Kota Banjarbaru

Dharmawati, S. dan Budirakhman, R., 2003. Kinerja dan Kadar Lemak Daging Itik Alabio Jantan ( Anas plathyrhyncos Borneo) dengan Pemberian Azolla Sp. Daun Eceng Gondok dan Gondok. Laporan Penelitian. Universitas Islam Kalimantan. Banjarmasin.

Dharmawati, S, 2006. Pengaruh Pengolahan Keong Mas terhadap Nilai Energi Metabolis dan Kecernaan Protein Serta Implikasinya pada Ayam Broiler. Thesis Program Pascasarjana Universitas Padjadjaran Bandung.

Dharmawati, 2008-2009. Kajian Nutrien Keong Rawa "Kalambuai" di Rawa Kalimantan Selatan dengan Menggunakan Metode Pengolahan Berbeda dan Penggunaannya pada Itik Alabio.

Rose, S.P. 1997. Principles of Poultry Science. CAB Internasional.

Soekartono, 2009. Ekonomi Agribisnis Peternakan Teori dan Aplikasinya. Akademika Pressindo. Jakarta 